\title{
CUSTOMER SUBJECTIVE PERCEPTION AS A MAIN ISSUE IN CONCEPTUAL PRODUCT DESIGN. A METHODOLOGICAL PROPOSAL
}

\section{LA PERCEPCIÓN SUBJETIVA COMO FACTOR PRIMORDIAL EN EL DISEÑO CONCEPTUAL DE PRODUCTOS. UNA PROPUESTA METODOLÓGICA}

\author{
Jaime A. León Duarte ${ }^{1} \quad$ Luis F. Romero Dessens ${ }^{1} \quad$ Jaime Olea Miranda $^{1}$ \\ Recibido 31 de octubre de 2007, aceptado 29 de mayo de 2008 \\ Received: October 31, 2007 Accepted: May 29, 2008
}

\begin{abstract}
RESUMEN
El escenario económico actual obliga a las organizaciones a implantar estrategias novedosas, dirigidas a incrementar su competitividad. El diseño industrial no es ajeno a esto; en la actualidad las organizaciones presumen que sus productos son resultado de escuchar al usuario. Sin embargo, este proceso se distingue por dos características: la naturaleza lingüística asociada al mismo y la dificultad para interpretar, categorizar y traducir las necesidades del usuario a especificaciones de producto.

En este sentido, es notoria la falta de mecanismos sólidos y confiables para traducir las necesidades en características de diseño; no únicamente aquellas palpables, sino que también los atributos intangibles relacionados con la percepción del producto.

Se presenta un mecanismo para la detección e interpretación de atributos de producto en la fase de diseño conceptual, de forma que no únicamente se identifican y categorizan las necesidades funcionales, sino que además se incluye un procedimiento para evaluar la percepción subjetiva del usuario.

Partiendo de una diferenciación inicial del tipo de requerimientos, se establecen mecanismos particulares para la detección, interpretación y categorización de las necesidades del usuario en dos vertientes básicas. Estas cualidades, una vez identificadas, son incorporadas en una estructura de affordances. Esta distribución servirá de guía para el equipo creativo en el diseño de detalle, incorporándose aquellos aspectos que el usuario valora mayormente; en la propuesta se retoman, entre otros, el método Kano de detección de requerimientos, la técnica de diferenciales semánticos de Osgood, el análisis factorial y la lógica difusa (fuzzy logic).
\end{abstract}

Palabras clave: Diseño industrial, affordances, kansei, diferenciales semánticos, método Kano, lógica difusa.

\section{ABSTRACT}

Present economic scenarios compel organizations to introduce new strategies directed to increase their competitiveness. Industrial design is not detached from this tendency; commonly organizations declare that their products are the effect of "listening to the user". Nevertheless, this process is identified by two basic characteristics: the associated linguistic nature to and the difficulty for interpreting, categorizing and incorporating the user's needs into product specifications.

In this sense, the lack of solid and reliable mechanisms to integrate the user's perceived requirements into product characteristics is well known. A particular emphasis is made on the need to incorporate intangible attributes related to product perception by the user. A mechanism to detect and interpret product attributes in the conceptual or early design and a procedure to evaluate the user's subjective perception are incorporated.

The methodology draws upon particular mechanisms for detection, interpretation and categorization of the requirements in two basic domains. These attributes, once identified, are incorporated in an affordances structure that shows sets of interactions in which the properties of the object are perceived by the user as action possibilities. This structure serves as a guide for the creative team in the detailed design phase, incorporating aspects that the user values the most, employing a combination of mechanisms that include the Kano method, Osgood's semantic differentials, factor analysis, and fuzzy logic.

Keywords: Industrial design, semantic differentials, affordances, kansei, Kano method, fuzzy logic.

\footnotetext{
1 Departamento de Ingeniería Industrial. Universidad de Sonora. Avenida Rosales y Bulevar Luis Encinas C.P. 83000. Hermosillo, México. Phone (+52) 6622592160, (+52) 6622112071. E-mail: jleond@industrial.uson.mx. URLs: www.uson.mx, http://www.uson.mx/u_academicas/diving.htm
} 


\section{INTRODUCTION}

Industrial design in engineering has been historically understood using reductionist approaches, where a simple aesthetic perspective is taken and thought far away from the classic engineering design vision, which provides an object shape based on the object's structure and purpose. This perspective is closer to design's purpose, which only concentrates on function analysis. A new approach suggests that industrial design engineering centers between the traditional engineering vision and industrial design. There is not an industrial design engineering definition but the description provided by Bonsiepe [1] is considered:

"Design is the efficient action produced by a structure, obtained from the interactions between an object and its user"

In this definition can be inferred that the focus is shifted from the design act to the output that design will provide. Twofold arises: firstly, the restrictive perspective related to a very general design technique is overcome and secondly, the design output is not necessarily an object but the interaction domain between the user and an object.

\section{The meaning of affordance}

Affordance theory belongs to perception psychologist James J. Gibson [2], which defines it as:

"The affordances of the environment are what it offers the animal, what it provides or furnishes, either for good or ill. The verb to afford is found on the dictionary, but the noun affordance is not. I have made it up. I mean by it something that refers to both the environmental and the animal in a way that no existing term does. It implies the complimentary of the animal and the environment".

Although there is not an accepted translation in Spanish, some authors have defined it. Donald Norman [3] uses the word prestaciones ${ }^{2}$, while another researchers use permisividad, habilitacion, oportunidades ambientales ${ }^{3}$ [4], or invitaciones al uso 4 [5]. Carlos Scolari points that "the affordance opposite are its constraints: objects not only communicate their function, they also communicate things that are not allowed to perform". Affordance meaning varies too much, however environmental opportunity is the closest to the author's vision.

Besides the term applied, the relevance of the twofold critical meaning to design cannot be misunderstood: the

\footnotetext{
2 Benefits.

3 Permissions, habilitations, environmental opportunities.

4 Use invitations.
}

affordance design ${ }^{5}$ and the information specified by the affordances. This is, considering usefulness in a product design is related but independent of its usability [6].

Traditionally the design activities have been based in the object functionality and recently in its usability, as mentioned by Norman [7]:

"The designer cares more about what actions the user perceives to be possible that what it is true"

The designer should consider only the useful actions that an object can attain; adding information about what is possible for the object to perform, since a useful design takes proper functions required by a user to satisfy its requirements. The usefulness of the design object is then defined by the affordances considered, or instead, the object's action possibilities are in conformance with the affordances incorporated as characteristics. The usefulness and the affordance liaison between usability and the specific information provided by an affordance can be understood in figure 1 .

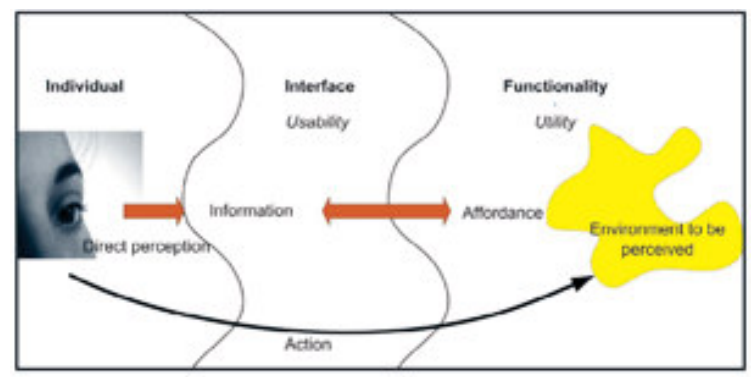

Figure 1. Utility and usability [9].

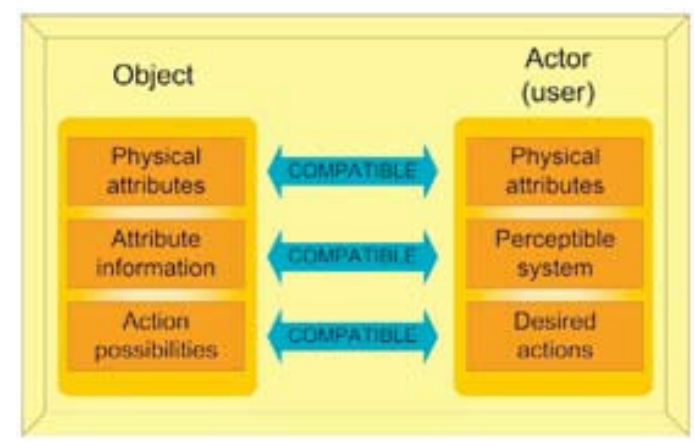

Figure 2. Required properties for affordances.

Considering affordances in a design also requires a special properties mix. Firstly, it implies that physical attributes of an object must be user compatible; furthermore, the object's attribute information must be compatible with the user's perceptive system. Lastly, attributes and actions that make

5 Afterwards, italics will not be used to highlight this term. 
the object valuable to the user's perception and compatible with its own physical characteristics (figure 2).

\section{A METHOD PROPOSAL FOR AFFORDANCE STRUCTURE CONSTRUCTION}

This proposal is suitable mostly for new product design (as is the case of the application project described forward), but also applies to redesign of products already on the market, where there are usually some constraints related to the original design properties (e.g. dimensions, manufacturing processes, mechanical characteristics, etc.)

This proposal suggests a method to identify, classify and categorize affordances and include them into product design. The purpose of having an affordance structure is that this classification supports any creative activity performed by the design team, after the concept generation stage.

Systematic design is based in how user's requirements can be translated into functions related to physical principles of the artifact behavior to be performed by different elements or components [8] [9]. Following a series of detailed steps, on this type of methods it is reasonable to expect a better design proposal; however, it is still not clear that these results are due to a functional or systematic approach; what should be questionable is the engineering design ubiquity instead of the design process systematization. It should be clear that considering affordance as an alternate design process then a systematic approach to affordance design should make sense.

\section{Required steps to create an affordance structure}

Step 1. User's information should be gathered, comprehended and expressed in terms of affordances. From a psychological perspective, this seems not complicated, since ecological psychology proposes that people communicate their perceptions in terms of affordances; however, generally is simpler to state affordances using relations instead of using a word or verb to refer an affordance. The result of this stage is an affordance list as they were stated by the user.

Step 2. Apply a generic method to structure affordances. For this, it is necessary to compare the obtained affordance list and those present in the generic structure. It should be noted that affordances present in the generic structure and not present on the requirements list should be evaluated by the designer to decide if they are really important to the project.

Step 3. Affordance ordering. The result in this step should be a one-dimensional, attractive and obligatory requirement list. Considering the affordance ordering then the characteristics can be combined to produce different product levels, as shown in table 1.

Table 1. Affordance mix by product type (Adapted from [10]).

\begin{tabular}{|l|l|}
\hline \multicolumn{1}{|c|}{$\begin{array}{c}\text { Product } \\
\text { Type }\end{array}$} & \multicolumn{1}{c|}{$\begin{array}{c}\text { Required Affordances under } \\
\text { Kano's classification }\end{array}$} \\
\hline Basic Product & $\begin{array}{l}\text { Obligatory Affordances: Those that } \\
\text { should always be in the object }\end{array}$ \\
\hline Product & $\begin{array}{l}\text { Obligatory affordances + one- } \\
\text { dimensional affordances: those } \\
\text { that directly increase the user's } \\
\text { satisfaction level given their degree } \\
\text { of presence in the object }\end{array}$ \\
\hline $\begin{array}{l}\text { Enhanced } \\
\text { Product }\end{array}$ & $\begin{array}{l}\text { Obligatory affordances + one- } \\
\text { dimensional affordances + } \\
\text { attractive affordances: are those } \\
\text { that provide the object with novel } \\
\text { characteristics that are not provided } \\
\text { by similar objects even those with } \\
\text { the same function }\end{array}$ \\
\hline $\begin{array}{l}\text { Potential } \\
\text { Product }\end{array}$ & $\begin{array}{l}\text { Obligatory affordances + one- } \\
\text { dimensional affordances + } \\
\text { incorporated attractive affordances } \\
+ \text { attractive affordances not } \\
\text { incorporated }\end{array}$ \\
\hline
\end{tabular}

Step 4. Reorganize affordances into a structure. This step can be done in many ways, one of them is to classify affordances by topic through an adaptation of the generic structure.

\section{Affordance theory use}

Considering the affordances vision as a fundamental theory regarding design, it should be thought as a multidisciplinary activity for object deployment, considering the many issues that should be taken into a product. There are no concrete methodological procedures as theoretical basis to identify, measure and classify those subjective affordances related to a product and how its user perceives it. Consequently, a design decision making procedure is suggested, oriented to develop a product twofold: based in functional characteristics and in the user's aesthetical and emotional needs concerning an object. Its theoretical foundation is briefly described, as follows:

1. Treatment proposal for functional requirements. To classify and order this kind of requirements, Kano's method for customer satisfaction [10-12] is suggested, together with Saaty's [13] analytic hierarchy process. Kano's method establishes that for each customer requirement the 
liaison between satisfaction and functionality may allow to discriminate and classify requirements. Obligatory requirements are the expected attributes or "musts" of a product, and do not provide an opportunity for product differentiation. Increasing the performance of these attributes provides diminishing returns in terms of customer satisfaction; however the absence or poor performance of these attributes results in extreme customer dissatisfaction.

One-dimensional requirements are those for which more is generally better, and will improve customer satisfaction. Conversely, an absent or weak performance attribute reduces customer satisfaction. Of the needs customers verbalize, most will fall into the category of One-dimensional requirements. Attractive requirements are unspoken and unexpected by customers but can result in high levels of customer satisfaction; however their absence does not lead to dissatisfaction. These kind of requirements often satisfy latent needs -real needs of which customers are currently unaware-. In a competitive marketplace where manufacturers' products provide similar performance, providing excitement attributes that address "unknown needs" can provide a competitive advantage. Figure 3 explains Kano's proposal.

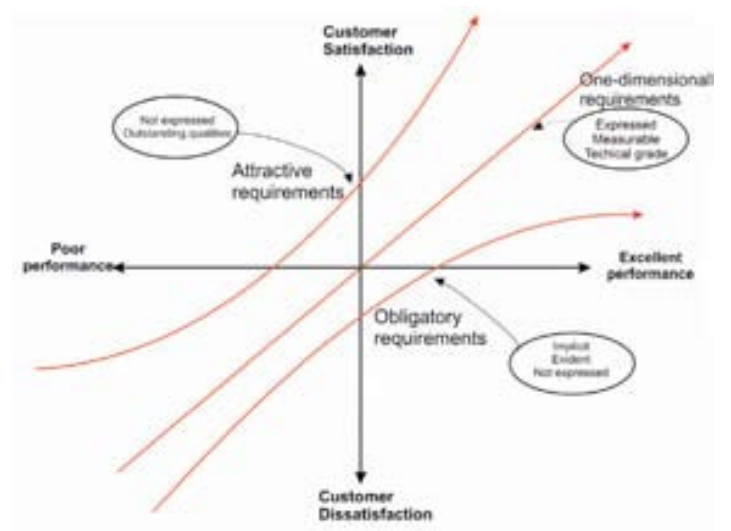

Figure 3. Kano's [10] Product Requirement Classification.

Since customers have many requirements, it is very important to have a proper mix attributes incorporated to the product. It should be taken: all obligatory requirements (which support a basic product), a reasonable amount of one-dimensional requirements (which are equivalent to have an expected competitive product) and some attractive requirements (enhanced product).

2. Proposed approach for emotional requirements. In this case, the Kansei technique is used [14]. This technique begins reducing data available through factor analysis [15-16] based in data obtained using Osgood's semantic differentials technique [17-19]. Osgood's semantic differential was designed to measure the connotative meaning of concepts. The respondent is asked to choose where his or her position lies, on a scale between two bipolar words, or a range of words or numbers ranging across a bipolar position (for example, 'Excellent', 'Good', 'Adequate', 'Poor', 'Inadequate'). The development of this instrument provides an interesting insight into the border area between linguistics and psychology. The purpose of the semantic differentials technique is to supply a quantitative support that allows having an objective measurement of a product psychological meaning to a customer. As said, this requires descriptive scales with bipolar adjectives to establish the similarity or discrepancy degree among the various issues. See figure 4.

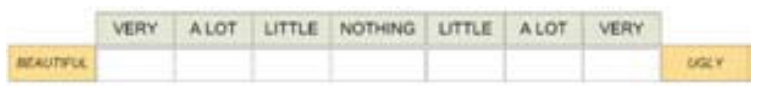

Figure 4. Semantic differential scale example.

Using factor analysis the number of semantic adjectives is reduced and also categorized. Factor analysis is a statistical data reduction technique employed to explain variability among observed random variables, in terms of fewer unobserved random variables named factors. The observed variables are modeled as linear combinations of the factors, plus "error" terms. This is a statistical analysis technique that identifies a structure from a set of variables. Its proper application implies the interrelation analysis between variables (using statistical covariance and correlations) to determine a new smaller set of variables than the original set; this new set describes the interrelations among the original variables [15]. When a large amount of variables is simultaneously collected, the researcher's interest may be to determine how the answers of a survey may be grouped. Applying a factorial analysis to the collected responses on a given questionnaire, it is possible to group responses with common meaning, reducing the number of required indicators to explain all the responses. This reduction is possible without the loss of an important part of the reliability in the original data (in the application case described forward, reducing the number of variables from 22 to seven resulted in the loss of $17 \%$ of reliability in the original data collected).

Factor analysis, compared to other techniques such as variance analysis or multiple regression, has the advantage that all the involved variables play the same role: they are independent (in a way that there is no prior conceptual dependence between variables). To reduce the processing time an information technology tool was adapted to fit the special conditions required by the technique in this proposal using XML technology (Extensible Markup Language). 
3. Qualitative requirements conversion tool into design specifications. This section is the essence of this proposal which is based in fuzzy set theory $[20]^{6}$, considered as a classical set theory generalization. In this classical set theory an element can belong or not to a set and its belonging to any set can be defined.

Fuzzy sets are a special kind of sets whose elements have degrees of membership. Fuzzy sets were introduced by Lotfi A. Zadeh [20] as an extension of the classical notion of set. In classical set theory, the membership of elements in a group is assessed in binary terms according to a bivalent condition -an element either belongs or does not belong to the set-. In contrast, fuzzy set theory allows the gradual assessment of the membership of elements in a set; this is described with the aid of a membership function valued in the real unit interval $[0,1]$. Fuzzy sets generalize classical sets, since the indicator functions of classical sets are special cases of the membership functions of fuzzy sets, if the latter only take values 0 or 1 . Classical sets are defined through a predicate that clearly divides the discourse of the universe $\mathrm{X}$ into "true" or "false" values. However, the human reasoning frequently uses predicates that cannot be reduced to this sort of values: these are known as vague predicates [20]. Fuzzy logic basically is a multi-valued logic that allows intermediate values such as "hotter" or "a bit cold" can be mathematically expressed. This way, a more human like of thinking is expressed using mathematical modeling.

\section{METHODOLOGY DEPLOYMENT}

Figure 5 shows the activity sequence that was developed in an application case and is used as a general reference to apply the methodology proposal. The case study is based in the design of a bipedestation electric chair. This kind of chair is a special aid for people with very limited or null moving capabilities on legs and arms; it allows the user to adopt a standing posture, which helps the user or healthcare personal to perform different activities.

On the applied survey, 103 people were personally or online interviewed. 55 of them were industrial designers and the rest users of this kind of product. The analysis on the collected data was performed in two stages: firstly based on Kanos's method [10] and secondly based on the semantic differentials technique. Derived from the information obtained in the latter stage, a fuzzy logic inference model was created to compare and select one of the evaluated products, starting with 14 initial input variables.

The methodology deployment is explained at detail in the next paragraphs.

6 Also known as fuzzy logic.

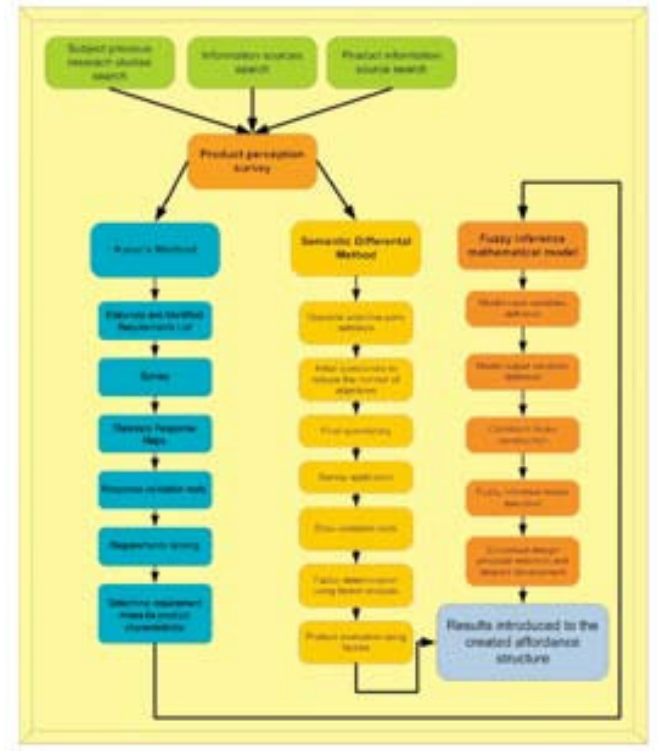

Figure 5. Proposed methodology sequence of activities.

\section{Functional requirement classification}

In this phase, 15 needs were taken and their classification was obtained using Kano's method for user's satisfaction, as shown in table 2. Departing from this information it is possible to establish the required affordances mixes to consider in the object, allowing to add more characteristics to generate different products levels, such as basic, enhanced or potential product combinations. Table 2 shows the obtained classification.

Table 2. Requirement classification based on obtained results.

\begin{tabular}{|l|l|}
\hline Requirement & Classification \\
\hline 1. Easy to drive & Obligatory \\
\hline 2. Easy to maintain & Attractive \\
\hline 3. appealing & Attractive \\
\hline $\begin{array}{l}\text { 4. Possibility of adding accessories: lights, } \\
\text { communication facilities and seat covers }\end{array}$ & Attractive \\
\hline $\begin{array}{l}\text { 5. Possibility to add seating accessories: } \\
\text { reclining variable position, arm supports } \\
\text { with variable height. }\end{array}$ & One-dimensional \\
\hline 6. Comfort. & One-dimensional \\
\hline 7. easy to change or fold & Indifference \\
\hline 8. Carry space. & Obligatory \\
\hline 9. Capable of absorbing surface imperfections & Obligatory \\
\hline 10. capable to respond in different surfaces & One-dimensional \\
\hline 11. Safety & Attractive \\
\hline 12. Price & Attractive \\
\hline 13. Autonomy (battery useful life) & Attractive \\
\hline 14. Ergonomic adaptability & One-dimensional \\
\hline 15. Durabilidad de componentes. & Obligatory \\
\hline
\end{tabular}




\section{Subjective (semantic) requirement classification}

As mentioned earlier, the semantic differential technique was applied to 20 pairs of adjectives, these adjectives describe subjective qualities (in this application, aesthetic issues) to be considered in the product. In figure 6 , it can be seen a semantic map that depicts 20 semantic differentials for each of the evaluated products.

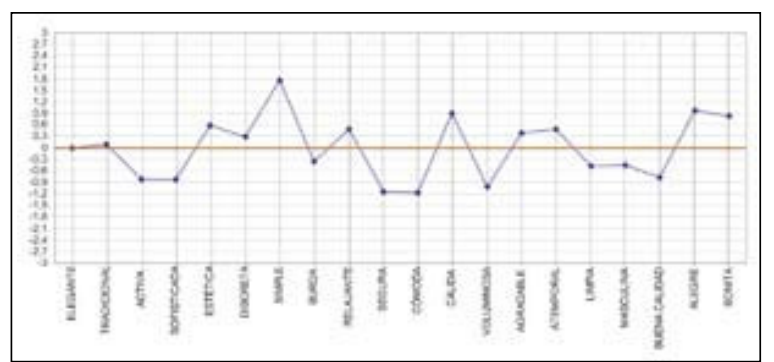

Figure 6. Semantic differentials map for one of the evaluated products.

The original 20 adjective pairs were reduced to 7 factors (Figure 7) using the factorial analysis. The decision to determine how many factors should be considered depends on the confidence increase (expressed as a percentage of the total variance explained by the quantity of factors taken) against the complexity produced by managing a larger set of factors.

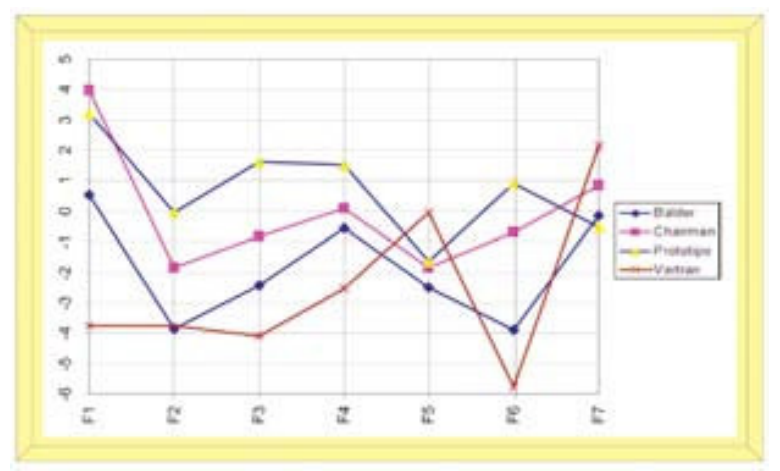

Figure 7. Semantic map for the reduced 7 factors.

\section{Fuzzy inference model}

The mathematical model developed depends on the information available from the design proposals, which was obtained from the semantic differentials technique. Additionally, it is important to have the results from the semantic adjective sets (identified through factor analysis) separated for each design proposal.

Fuzzy inference is the process of formulating the mapping from a given input to an output using fuzzy logic. This mapping provides a basis for decisions to be made, or patterns discerned. This process includes the modeling of membership functions, logical operations, and If-Then Rules. Figure 8 illustrates the procedure for this particular application.

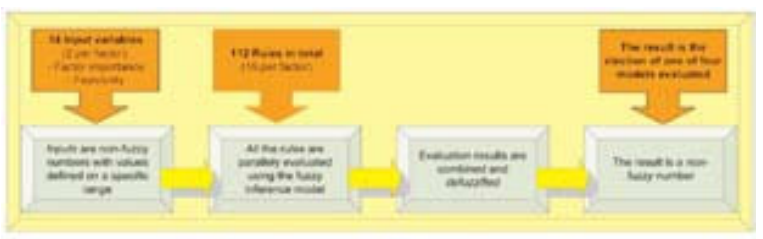

Figure 8. Fuzzy inference process used.

In summary, 112 restrictions were used for the mathematical model, produced by combining membership functions for the seven factors. Figure 9 shows the sixteen If-Then rules from one of the seven factors considered in this model.

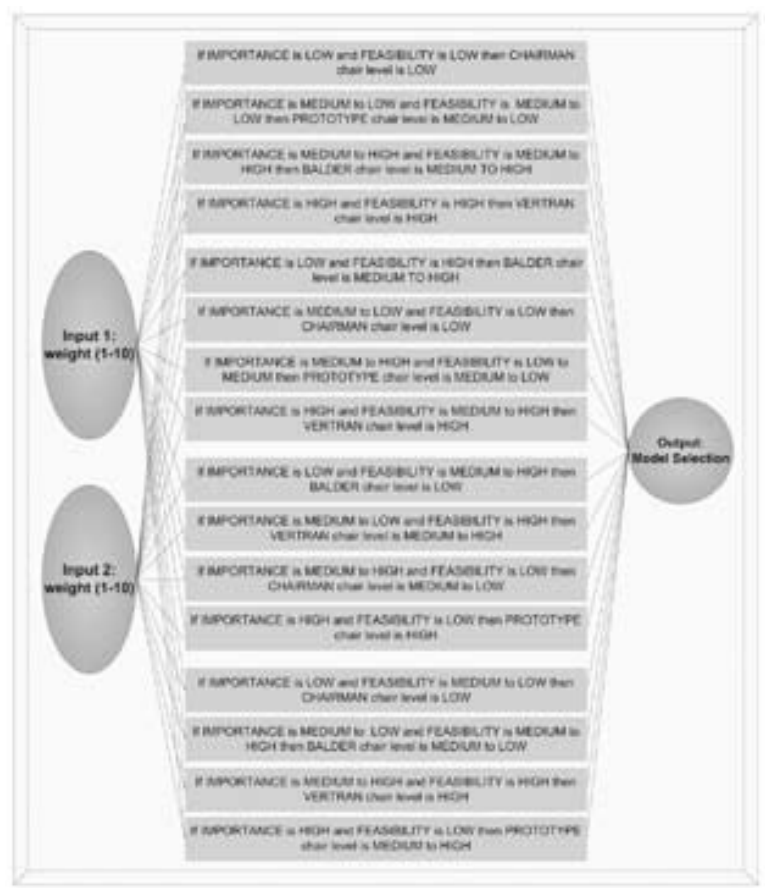

Figure 9. 16 restrictions considered for factor 1 in the mathematical model.

\section{FUZZY INFERENCE MODEL TESTING}

To verify the model stability against different value mixes from 14 input variable combinations, 20 tests were performed which demonstrated heterogeneous results as output variables. Table 3 shows results for 4 tests that are representative of the many output variables obtained and allowed to choose one of the four evaluated products. 
Obtained results from the fuzzy logic model for each test are shown in figure 10 , the 14 variable value combinations appear in the upper rectangle for each obtained result, the value for each output variable appears in the grey rectangle in the middle results, and finally the generated graphics for each output variable.

Figure 11 shows obtained results from each of the applied 4 testes depicted in figure 10 and display the best wheel chair that assess the input variables.

Table 3. Input values for the fuzzy inference model.

\begin{tabular}{|c|c|c|c|c|}
\hline Factor & P1 & P2 & P3 & P4 \\
\hline $\begin{array}{l}\text { Factor 1: } \\
\text { Importance } \\
\text { Technical } \\
\text { feasibility }\end{array}$ & $\begin{array}{l}6.0 \\
8.0\end{array}$ & $\begin{array}{l}8.0 \\
8.5\end{array}$ & $\begin{array}{l}5.0 \\
3.0\end{array}$ & $\begin{array}{l}3.0 \\
5.5\end{array}$ \\
\hline $\begin{array}{l}\text { Factor 2: } \\
\text { Importance } \\
\text { Technical } \\
\text { feasibility }\end{array}$ & $\begin{array}{l}9.0 \\
4.0\end{array}$ & $\begin{array}{l}5.0 \\
6.7\end{array}$ & $\begin{array}{l}2.4 \\
7.0\end{array}$ & $\begin{array}{l}7.0 \\
9.0\end{array}$ \\
\hline $\begin{array}{l}\text { Factor 3: } \\
\text { Importance } \\
\text { Technical } \\
\text { feasibility }\end{array}$ & $\begin{array}{l}7.0 \\
3.5\end{array}$ & $\begin{array}{l}8.0 \\
7.5\end{array}$ & $\begin{array}{l}3.8 \\
6.0\end{array}$ & $\begin{array}{l}4.0 \\
8.5\end{array}$ \\
\hline $\begin{array}{l}\text { Factor 4: } \\
\text { Importance } \\
\text { Technical } \\
\text { feasibility }\end{array}$ & $\begin{array}{l}4.0 \\
6.0\end{array}$ & $\begin{array}{l}8.0 \\
5.0\end{array}$ & $\begin{array}{l}5.0 \\
7.0\end{array}$ & $\begin{array}{l}3.0 \\
5.0\end{array}$ \\
\hline $\begin{array}{l}\text { Factor 5: } \\
\text { Importance } \\
\text { Technical } \\
\text { feasibility }\end{array}$ & $\begin{array}{l}8.0 \\
9.5\end{array}$ & $\begin{array}{l}3.5 \\
3.0\end{array}$ & $\begin{array}{l}6.0 \\
8.3\end{array}$ & $\begin{array}{l}7.0 \\
6.5\end{array}$ \\
\hline $\begin{array}{l}\text { Factor 6: } \\
\text { Importance } \\
\text { Technical } \\
\text { feasibility }\end{array}$ & $\begin{array}{l}7.5 \\
6.0\end{array}$ & $\begin{array}{l}8.8 \\
7.0\end{array}$ & $\begin{array}{l}3.7 \\
6.0\end{array}$ & $\begin{array}{l}9.0 \\
7.0\end{array}$ \\
\hline $\begin{array}{l}\text { Factor 7: } \\
\text { Importance } \\
\text { Technical } \\
\text { feasibility }\end{array}$ & $\begin{array}{l}8.3 \\
9.0\end{array}$ & $\begin{array}{l}8.1 \\
7.0\end{array}$ & $\begin{array}{l}8.1 \\
5.0\end{array}$ & $\begin{array}{l}6.5 \\
7.0\end{array}$ \\
\hline
\end{tabular}

\section{ATTACHING RESULTS TO THE AFFORDANCE STRUCTURE}

Based on the results and its statistical processing and mathematical modeling, the affordance structures can be formulated. They will set the work guidelines for the design team and also command the process to be followed during the detailed design phase. Following these guidelines, the product design will be focused on those very important details which are relevant in the customer's eyes and which will highlight the product in the customer's perception. This affordance ordering is also divided into two new areas: aesthetic perception and product usability characteristics.
Figure 12 depicts an affordance structure for an enhanced and expected product. These classifications arose from the case study depicted and are based on the following results: Kano's method for customer's satisfaction and those selected with the fuzzy logic inference model and related to aesthetic affordances. The selected conceptual detailed design (one of the wheel chair proposals) has to be chosen from the fuzzy inference model.

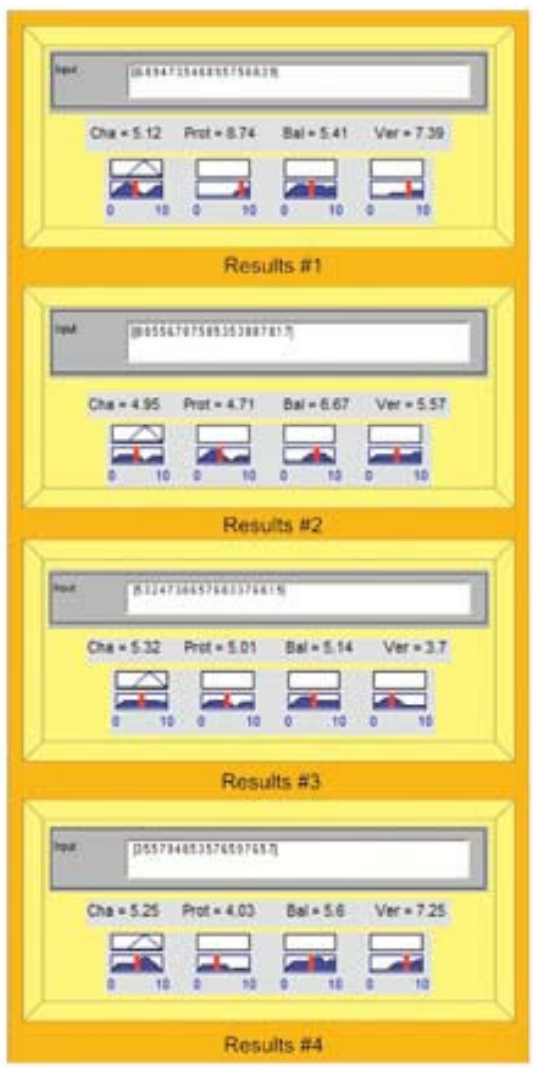

Figure 10. Results obtained for four mixes from the input variables from table 3 .

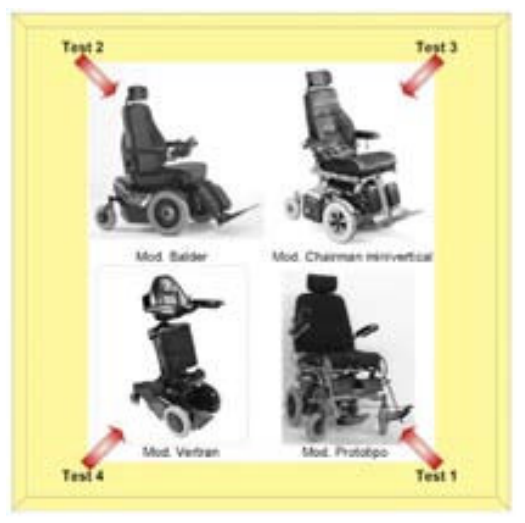

Figure 11. Selected wheel chairs based on results obtained from figure 10 . 


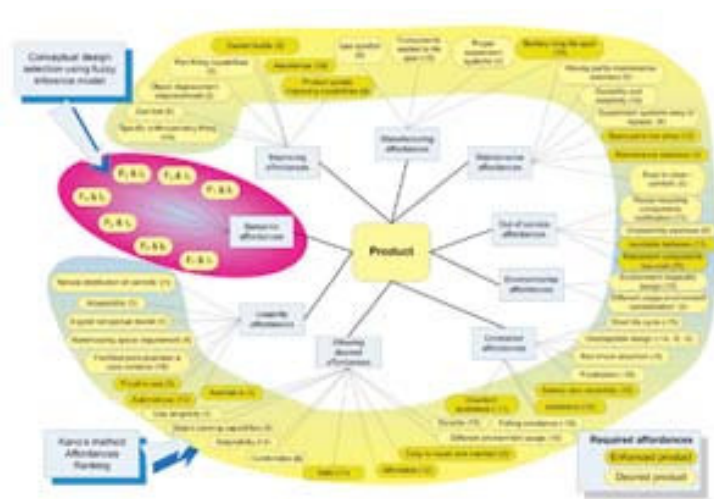

Figure 12. Affordance structure obtained by combining enhanced affordances.

\section{CONCLUSIONS}

Affordances represent a special interaction set in a broader artifact/user, user/artifact bi-directional sense. However, not all the interactions are affordances; this statement requires special attention from the designer because the object properties do not highlight an affordance by its own. This property is given by the degree level on which those properties are useful to the user.

Affordances can be defined following this interaction between the object and the user as an interaction set in which the object properties are perceived by the user as usage possibilities, then it can be stated that an object allows a mix of different uses. In this sense, and considering these results, it can be stated that this proposal provides an additional mechanism for design, which is an alternative to product design based only in a function analysis.

The main difference between function and affordance concepts is the interaction complexity measure described by each concept. A function describes a simple inputoutput relation in a kind of a "black box model"; instead, an affordance describes a more complex relation between the object properties and the user perception of how to use a product. This design complexity arises from multiple factors sharing the basic need of considering three essential issues: the artifact (product), the user and the designer.

As a result from the study case it has been shown that it is possible to have a mechanism to identify, among various object designs, a design proposal which is closer to satisfy the subjective requirements (semantic) which is wanted to externally be shown by the object. On the other hand, resultant structures allow to distinguishing different product levels associated to affordance mixes: basic, expected and an enhanced products. It seems clear that the complexity level obtained by each of these structures should be equivalent to the amount of action possibilities to be considered into product design.

The effectiveness of a design developed with the proposed methodology, in terms of market success and user appreciation is a pending and future subject to research. The principal obstacle in this kind of evaluation is the required lapse of time from the design proposal approval to market introduction.

\section{ACKNOWLEDGEMENTS}

The authors wish to thank the support and sponsorship for this investigation to:

The Mexican council of science and technology (Consejo Nacional de Ciencia y tecnología-CONACYT-) and the Programa de Repatriación de exbecarios CONACYT 2006.

The Engineering division and the department of Industrial Engineering, at the University of Sonora, for their support and facilities.

\section{REFERENCES}

[1] G. Bonsiepe. "Las 7 columnas del diseño". Editorial UAM-Unidad Azcapotzalco. $1^{\text {st }}$ edition. México, México D.F. 1993.

[2] J.J. Gibson. "The theory of affordances". The ecological Approach to Visual Perception, Houghton Mifflin. Boston, MA, p. 332. 1979.

[3] D. Norman. "La psicología de los objetos cotidianos". Editorial NEREA, S. A. $2^{\text {nd }}$ edition. 300 pages. San Sebastián, España. 2000.

[4] Dit-UPM. "Términos debatidos en spanglish". Grupo de Sistemas inteligentes. Universidad Politécnica de Madrid. WEB article. Consult date: October 15, 2006. URLs: http://www.gsi.dit.upm. es/ gfer/spanglish/

[5] C.A. Escolari. "Cliquear: hacia una teoría semiótica de los dispositivos interactivos". WEB article. Date of consult: July 12, 2007. URLs: http://www. indaba.com.mx/resource/proj_design/interfaz/ interfaz $\% 20 \mathrm{y} \% 20$ semi $\%$ F3tica.pdf 
[6] W.W. Gaver. "Technology affordances". Proceedings of the SIGCHI Conference on Human Factors in Computing Systems. New Orleans, Louisiana, pp. 79-84. 1991.

[7] D. Norman. "Affordance, Conventions and Design (Part 2)". Originally published as Affordance, conventions and Design on the May 1999 issue of Interactions, pp. 38-43. WEB article. Date of consult: July 18, 2007. URLs: http://www.jnd.org/ dn.mss/affordance_conv.html

[8] G. Pahl and W. Beitz. "Engineering design, a systematic approach". $2^{\text {nd }}$ edition. Springer cop. London, England, p. 544. 1999.

[9] W. E. Hubka. "Engineering Design: General Procedural Model of Engineering Design". Heurista, Zurich, p. 133. 1993.

[10] N. Kano. "Attractive Quality and Must-Be Quality". Japanese Society for Quality Control Journal. Vol. $14 \mathrm{~N}^{\mathrm{o}}$ 2, pp. 147-156. 1984.

[11] Center for Quality Management. Center for Quality Management Special Edition on the Kano Method. Vol. $2 \mathrm{~N}^{\circ}$ 4. Cambridge Ma. 1993.

[12] D. Fong. "Using the Self-Stated Importance Questionnaire to interpret Kano Questionnaire results". Center for Quality Management Journal. Vol. $5 \mathrm{~N}^{\circ}$ 3, pp. 21-24. 1996.

[13] T. L. Saaty. "The Analytic hierarchy process: planning, priority setting, resource allocation". Mc Graw-Hill, p. 287. 1980.
[14] M. Nagamachi. "Kansei engineering: a new ergonomic consumer-oriented technology for product development". International Journal of industrial ergonomics. Vol. $15 \mathrm{~N}^{\circ} 1$, pp. 3-11. 1995.

[15] M. Santesmases Mestre. "Diseño y análisis de encuestas en investigación social y de mercados". $1^{a}$ edición. Ediciones Pirámide. S.A. Madrid, España. 1997.

[16] E. B. Hayes. "Measuring Customer Satisfaction: Survey Design, Use, and Statistical Analysis Methods". $2^{\text {nd }}$ edition. American society for Quality, Wisconsin, p. 285. 1998.

[17] C.E. Osgood. "The measurement of meaning". University of Illinois Press. $2^{\text {nd }}$ edition. E.U, p. 360. 1957.

[18] M. Nagamachi. "Kansei engineering as a powerful consumer-oriented technology for product development". Applied ergonomics. Vol. $3 \mathrm{~N}^{\mathrm{o}} 3$, pp. 289-294. 2002.

[19] M. Nagamachi. "Kansei engineering: the implication and applications to product development". Systems, man and cybernetics, Vol. $199 \mathrm{~N}^{\circ} 6$, pp. 273-278. 1999.

[20] L.A. Zadeh. "Fuzzy Sets". Information and Control. Vol. $8 \mathrm{~N}^{\mathrm{o}}$ 3, pp. 338-353. 1965.

[21] E. Yacuzzy y F. Martín. “Aplicación del método de Kano en el diseño de un producto farmacéutico". Fecha de consulta: 20 de julio 2007. URLs: http://www.cema.edu.ar/publicaciones/download/ documentos/224.pdf 